\title{
Cechy temperamentalne jako czynnik ryzyka patologicznego skubania skóry
}

\author{
Alina Kałużna-Wielobób* \\ Katedra Psychologii, Uniwersytet Pedagogiczny im. KEN, Kraków \\ Katarzyna Prochwicz \\ Instytut Psychologii, Uniwersytet Jagielloński, Kraków
}

TEMPERAMENTAL FEATURES AS A PATOLOGICAL SKIN PICKING RISK FACTOR

\begin{abstract}
Pathological skin picking (dermatillomania) is a disorder characterised by repetitive, frequently ritualised, skin picking, scratching, rubbing or pinching, leading to its damage and to stress and problems in social life. The research was aimed at verifying the hypothesis about the connection between pathological skin picking and temperament. 216 women were examined (89-skin pickers and 125-control group). Occurrence and intensity of pathological skin picking was examined with Polish versions of questionnaires: SPS - Pathological Skin Picking Scale (Keuthen \& all, 2001), MIDAS - The Milwaukee Inventory for the Dimensions of Adult Skin (Walther \& all, 2009). To evaluate temperament characteristics, Temperament Questionnaire was used - Formal Behaviour Characteristics (FCZKT) (Zawadzki \& Strelau, 1997). People who pick skin are characterised by: higher perseveration, higher emotional reactivity and lower resilience and briskness than people who do not pick skin. Among skin pickers, people who exhibit automatic skin picking are characterised by higher reactivity and lower resilience than people, who exhibit focused skin picking.
\end{abstract}

Key words: pathological skin picking, dermatollomania,temperament

\section{WPROWADZENIE}

Celem prezentowanych badań było lepsze poznanie specyfiki zachowania, jakim jest powtarzajace się, nawykowe skubanie skóry, które w nasilonej postaci nabiera charakteru zaburzenia: dermatillomanii - patologicznego skubania skóry (pathological skin picking - PSP). Badania miały na celu weryfikację hipotezy o związkach patologicznego skubania skóry z temperamentem. Dermatillomania to zaburzenie charakteryzujace się występowaniem powtarzającego się, często zrytualizowanego uszkadzania skóry poprzez jej skubanie, drapanie, dłubanie, pocieranie, kłucie lub szczypanie (Arnold i in., 2001; Prochwicz i Starowicz, 2012). Skubanie może dotyczyć zarówno zdrowej skóry (Wilhelm, Keuthen i Deckersbach, 1999), jak i zmian trądzikowych, czy innych nierówności na skórze, np. blizn powstałych w efekcie wcześniejszego skubania (Deckersbach, Wilhelm i Keuthen, 2003; Hayes, Storch i Berianga, 2009). W projekcie klasyfikacji DSM-V, w którym patologiczne skubanie skóry (skin picking disorder) wyodrębniono po raz pierw-

\footnotetext{
* Korespondencję dotycząca artykułu można kierować na adres: Alina Kałużna-Wielobób, Katedra Psychologii, Uniwersytet Pedagogiczny im. KEN, ul. Podchorążych 2, 30-084 Kraków.
} akaluzna@up.krakow.p szy jako odrębną jednostkę diagnostyczna, wymieniane sa następujące kryteria diagnostyczne tego zaburzenia: nawracajace skubanie skóry prowadzace do jej uszkodzenia, powtarzajace się próby zaprzestania lub ograniczenia skubania, występowanie stresu lub spowodowanych skubaniem problemów w funkcjonowaniu społecznym, zawodowym lub w innych ważnych obszarach życia (Stein i in., 2010). Dane dotyczace rozpowszechnienia patologicznego skubania skóry nie sa jednoznaczne, co wydaje się być związane z różnymi kryteriami diagnostycznymi, stosowanymi w dotychczasowych badaniach. Łagodne postaci PSP, w których skubanie nie prowadzi do uszkodzenia tkanek, ani do zaburzeń funkcjonowania społecznego, występują stosunkowo często (Bohne i in., 2002; Keuthen i in., 2000). Samo zachowanie: skubanie, pocieranie lub drapanie skóry obserwuje się u ponad $60 \%$ osób w populacji ogólnej (Hayes, Storch i Berianga, 2009). Skubanie skóry powiązane z występowaniem stresu albo zakłóceń w funkcjonowaniu społecznym dotyczy 1,4\% osób dorosłych (Keuthen i in., 2010), natomiast obecność wszystkich objawów PSP, czyli wyraźne zmiany w wyglądzie, przeżywanie stresu przy jednoczesnym występowaniu zaburzeń w funkcjonowaniu społecznym będących konsekwencja skubania, takich jak np. nieobecność w pracy czy w szkole, stwierdzono u ok. $2 \%$ populacji (Keuthen i in., 2010). Zachowania polegające na skubaniu skó- 
ry szczególnie często występują u studentów: według badań Hajack, Franklin, Simons i Keuthen (2006) około 30\% studentów amerykańskich uczelni okazjonalnie skubie skórę, natomiast badania Bohne i in. (2002) Calikuşu, Kucukgoncu i Bestepe (2011) oraz Keuthen i in. (2000) wskazuja, że łagodne formy skubania można zaobserwować aż u 80-90\% osób z tej grupy. Cięższe postaci PSP prowadzące do znacznych uszkodzeń tkanek, występuja u około 4\% studentów w Stanach Zjednoczonych, Niemczech i Turcji (Bohne i in., 2002, Calikuşu, Kucukgoncu i Bestepe, 2011; Keuthen i in., 2000).

Patologiczne skubanie skóry nie jest zjawiskiem jednorodnym, można wyodrębnić co najmniej dwa typy tego zaburzenia: typ skoncentrowany na czynności skubania (focused skin picking) oraz typ automatyczny (automatic skin picking) (Arnold i in., 1998). W wypadku skubania skóry skoncentrowanego na czynności osoba jest świadoma, że skubie skórę w czasie, kiedy to robi (Neziroglu, Rabinowitz, Breytman i Jacofsk, 2008; Walther i in., 2009), natomiast skubanie automatyczne charakteryzuje się tym, że osoba nie uświadamia sobie, że skubie skórę $\mathrm{w}$ trakcie wykonywania tej czynności (Walther i in., 2009). Skubanie „skoncentrowane” zwykle poprzedzane jest stanem nieprzyjemnego napięcia, które może być rozładowane jedynie poprzez czynność skubania, natomiast skubanie automatyczne często występuje podczas innej aktywności absorbującej uwagę, np. podczas oglądania telewizji czy prowadzenia samochodu (Arnold i in., 1998; Fruensgaard, 1984) i zwykle nie jest związane $\mathrm{z}$ odczuwaniem napięcia.

Do najważniejszych komplikacji medycznych będących skutkiem patologicznego skubania skóry zalicza się powstawanie blizn, przebarwien, krwawień, infekcji, stanów zapalnych i innych zmian na powierzchni skóry, które negatywnie wpływają na jej wygląd. U osób cierpiacych na PSP powszechne jest niezadowolenie ze swojego wyglądu, gdyż skubane są przede wszystkim miejsca łatwo dostępne, a więc również dobrze widoczne, takie jak twarz czy ramiona i szyja. Do psychologicznych następstw patologicznego skubania skóry zalicza się poczucie winy, wstydu i obniżony nastrój (Snorrason, Smári i Olafsson, 2010; Wilhelm, Keuthen i Deckersbach, 1999) oraz odczuwanie dotkliwego stresu (Hajack, Franklin, Simons i Keuthen, 2006; Keuthen i in., 2010; Neziroglu, Rabinowitz, Breytman i Jacofsk, 2008). Wiele osób skubiacych skórę przyznaje, że z powodu wywołanych skubaniem zmian w wyglądzie zewnętrznym opuszczało szkołe lub pracę zawodowa, unikało kontaktów społecznych, a nawet przebywania w miejscach publicznych (Simeon i in., 1997; Wilhelm, Keuthen i Deckersbach, 1999; Keuthen i in., 2010). Osoby te cechuje także niższa jakość życia niż osoby z ogólnej populacji (Odlaug, Kim i Grant, 2010).

Prezentowane badania maja na celu uzyskanie odpowiedzi na pytanie, czy cechy temperamentu moga być jednym z czynników ryzyka patologicznego skubania skóry. Pytanie to wydaje się uzasadnione z kilku powodów. Po pierwsze analiza wyników dotychczasowych ba- dań sugeruje, że występowanie patologicznego skubania skóry wydaje się być powiązane zarówno z poziomem pobudzenia, jak i z emocjami. Według Penzel'a (2003) skubanie skóry może być mechanizmem regulującym poziom pobudzenia i może wystapić w dwóch przypadkach: w stanach silnego pobudzenia emocjonalnego oraz w stanach obniżonego pobudzenia, np. gdy osoba doświadcza uczucia nudy. Badania (Prochwicz, Kałużna-Wielobób i Starowicz, 2014, w recenzji) potwierdziły, że osoby skubiące skórę charakteryzują się wyższym poziomem napięcia, a niższym poziomem ogólnej aktywacji (general activation) dajacej poczucie energii i wigoru oraz ogólnej deaktywacji (general deactivation) - stanu spokoju i relaksu, niż osoby nieskubiące skóry. Niektóre dane sugerują także, że czynność skubania może pełnić funkcję regulatora poziomu pobudzenia oraz emocji. Osoby skubiące skórę twierdza, że czynność ta pomaga im obniżyć poziom lęku lub złości, a według niektórych jest również źródłem przyjemności (Snorrason, Smári i Olafsson, 2010). Można założyć, że skoro skubanie jest powiązane między innymi z poziomem aktywacji (jako stanem), to może być również powiązane $\mathrm{z}$ cechami temperamentu, a w szczególności z dyspozycją do reagowania na różne sytuacje danym poziomem aktywacji (reaktywność) oraz jego średnim poziomem u danej jednostki.

Osoby dotknięte patologicznym skubaniem skóry charakteryzują się podwyższonym poziomem lęku, także stosunkowo często występują u nich zaburzenia lękowe (Arnold i in., 1998; Calikuşu, Yücel, Polat i Baykal, 2003; Deckersbach, Wilhelm i Keuthen, 2003; Lochner i in., 2002; Odlaug, Brian i Grant, 2008; Wilhelm, Keuthen i Deckersbach, 1999). Poziom lęku-cechy, jak również podatność na zaburzenia lękowe są powiązane z cechami temperamentu: przede wszystkim z reaktywnościa emocjonalna, ale również z perseweratywnością i żwawością (Strelau i Zawadzki, 2011).

Badanie związków między skubaniem skóry a temperamentem wydaje się uzasadnione także w kontekście obserwacji, że skubanie skóry nasila się w okresach stresu egzaminacyjnego (Hajack, Franklin, Simons i Keuthen, 2006), a cechom temperamentu przypisuje się status mediatora lub moderatora reakcji na stres (Strelau i Doliński, 2011). Badania Marszał-Wiśniewskiej, Goryńskiej i Strelaua (2012) ujawniły związki cech temperamentu ujmowanego w kategoriach regulacyjnej teorii temperamentu (reaktywności emocjonalnej i perseweratywności), ze zmianami nastroju w sytuacji stresu egzaminacyjnego, natomiast badania Heszen (2012) wykazały zwiazki między cechami temperamentu ujmowanymi w ramach tej samej teorii, a sposobami radzenia sobie/zmagania się $\mathrm{z}$ długotrwałym stresem (coping activity).

Temperamentalne uwarunkowania może mieć także obecna u osób z PSP gotowość do wykonywania powtarzalnych, stereotypowych ruchów, niezdolność do powstrzymania się od tych zachowań, oraz niezdolność do ich zakańczania, gdy raz zostaną zainicjowane. Mimo silnej motywacji i przykrych następstw tej czynności, osoby cierpiące na dermatillomanię nie potrafią zaprzestać 
skubania, a nawet odroczyć go w czasie (Arzeno-Ferro i in., 2006). Osoby te twierdzą także, że skubaniu skóry towarzyszy odczucie transu lub „zahipnotyzowania”, uniemożliwiającego jego przerwanie. Wydaje się, że gotowość do wykonywanie powtarzalnych, stereotypowych ruchów, przy jednoczesnym ograniczeniu zdolności do przerwania raz zainicjowanej aktywności, także może mieć źródło w cechach temperamentu.

W naszych badaniach w celu operacjonalizacji zmiennych temperamentalnych, również odwołamy się regulacyjnej teorii temperamentu Strelau'a (2006a,b). Koncepcja ta wyróżnia sześć podstawowych wymiarów temperamentu: 1) żwawość (tendencję do szybkiego reagowania, utrzymywania wysokiego tempa aktywności i łatwej zmiany zachowania w razie potrzeby), 2) persewartywność (tendencja do kontynuowania, powtarzania zachowań oraz utrzymywania się stanów emocjonalnych po zaprzestaniu działania bodźca), 3) wrażliwość (zdolność do reagowania na bodźce o małej wartości stymulacyjnej), 4) reaktywność emocjonalna (tendencja do silnego reagowania na bodźce wywołujace emocje), 5) wytrzymałość (zdolność adekwatnego reagowania w warunkach długotrwałej i silnej stymulacji), 6) aktywność (tendencja do podejmowania zachowań o dużej wartości stymulacyjnej) (Strelau, 2006a,b).

Prezentowane badania zostały przeprowadzone na grupie studentów, gdyż są to osoby szczególnie narażone na ryzyko zachowań samouszkadzajacych oraz negatywnych psychologicznych następstw uszkodzenia skóry. Jak wcześniej wspomniano, badania (Hajack, Franklin, Simons i Keuthen, 2006; Bohne i in., 2002; Calikuşu, Kucukgoncu i Bestepe, 2011; Keuthen i in., 2000) pokazały, że patologiczne skubanie skóry występuje w tej grupie stosunkowo często. Studenci są grupą szczególnie uwrażliwioną z uwagi na stres związany z egzaminami, który może nasilać skubanie skóry (Hajack, Franklin, Simons i Keuthen, 2006). W wielu przypadkach czynnikiem stresogennym może być też oddzielenie od rodziny, konieczność zaaklimatyzowania się w nowym środowisku. Dla osób w wieku 19-25 lat wygląd zewnętrzny jest szczególnie ważny ze względu na znaczenie atrakcyjności dla osób płci przeciwnej, gdyż wchodzenie we wczesna dorosłość wiąże się często z poszukiwaniem intymnego partnera. W części przypadków jest to okres pierwszych kontaktów seksualnych, w kontekście których poczucie atrakcyjności własnego ciała oraz swojego stosunku do własnego ciała nabiera szczególnego znaczenia. Ponadto $\mathrm{u}$ niektórych osoby $\mathrm{w}$ tym wieku nadal występuje trądzik. Przełom wieku młodzieńczego i wczesnej dorosłości jest okresem szczególnej wrażliwości również z uwagi na proces poszukiwania i dookreślania własnej tożsamości.

\section{METODA}

\section{PYTANIA BADAWCZE I HIPOTEZY}

Celem badania było uzyskanie odpowiedzi na pytanie, czy skubanie skóry ma związek z cechami temperamen- tu, i jaki jest charakter tych powiąań. Postawiono hipotezę, że taki związek istnieje, a osoby skubiące skórę będa charakteryzować się wyższą reaktywnością i perseweratywnościa, a mniejszą wytrzymałościa, niż osoby nieskubiące skóry. Postawiono również hipotezę, że osoby skubiące skórę w sposób automatyczny, będą różniły się w zakresie temperamentu od osób, które skubią skórę świadomie.

\section{OSOBY BADANE}

W badaniu wzięły udział 2 grupy kobiet, studentek Uniwersytetu Pedagogicznego. Grupy te wyodrębniono w oparciu o wyniki Skali SPS oraz informacje uzyskane w ankietach dotyczących skubania skóry. Grupe pierwszą stanowiły kobiety skubiące skórę, czyli te, które w Skali SPS uzyskały wynik co najmniej 1 oraz w ankiecie informowały, że występują u nich objawy dermatillomanii o różnym nasileniu. Średnia wieku osób z tej grupy wynosiła 21.64 lat $(S D=1.85)$. Osoby te uzyskały w Skali SPS średni wynik 5.18 punktów ( $S D=3.69)$. Grupę kontrolną stanowiły studentki, które nie skubią skóry, czyli te, które w Skali SPS uzyskały wynik 0 oraz w ankiecie potwierdziły, że zachowania polegające na skubaniu skóry nie występuja u nich, i nie występowały nigdy wcześniej. Średnia wieku badanych z tej grupy wynosiła $23.00(S D=7,91)$ i nie była istotnie różna od średniej wieku kobiet skubiących skórę $(t=1.59, d f=212, p<.11)$. W badaniach brały udział kobiety, gdyż patologiczne skubanie skóry występuje głównie u kobiet, według niektórych szacunków kobiety stanowia aż 80-94\% wszystkich cierpiacych na dermatillomanię (np. Arnold i in., 1998; Wilhelm, Keuthen i Deckersbach, 1999; Hayes, Storch i Berianga, 2009).

\section{METODY BADANIA}

\section{Formalna Charakterystyka Zachowania - Kwestionariusz Temperamentu (FCZ-KT) (Zawadzki i Strelau, 1997)}

Kwestionariusz ma charakter samoopisowy. Składa się ze 120 pozycji, które są stwierdzeniami wymagającymi od badanego ustosunkowania się $\mathrm{w}$ formie odpowiedzi „Tak” lub „Nie”. Pozycje tworzą 6 podskal, dotyczących: Żwawości, Perseweratywności, Wrażliwości sensorycznej, Reaktywności emocjonalnej, Wytrzymałości i Aktywności. Teoretyczna podstawę kwestionariusza stanowi Regulacyjna Teoria Temperamentu przedstawiona w pracach J. Strelaua (Zawadzki i Strelau, 1997).

Pathological Skin Picking Scale (SPS) (Keuthen i in., 2001). SPS jest skalą składająca się z 6 pytań odwołujących się do sześciu aspektów zachowań związanych ze skubaniem skóry: częstotliwości odczuwania potrzeby skubania skóry, siły pragnienia skubania skóry, ilości czasu poświęcanego skubaniu, negatywnego wpływu skubania skóry na życie towarzyskie i zawodowe, stresu i cierpienia spowodowanego skubaniem skóry oraz unikania aktywności w konsekwencji skubania. W odniesieniu do każdego aspektu osoba badana ocenia swoje 
zachowanie na 5-punktowej skali (od 0 do 4). Skala SPS odwołuje się do zachowań, które wystapiły w ciagu ostatniego tygodnia. W badaniach użyto polskiego tłumaczenia Skali SPS (a Cronbacha dla polskiego tłumaczenia skali wynosiła .88)

The Milwaukee Inventory for the Dimensions of Adult Skin Picking (MIDAS) (Walther $i$ in., 2009)

MIDAS to 12-itemowa skala służąca do badania stylów skubania skóry. Skala składa się z dwóch podskal: podskali stylu skoncentrowanego na czynności skubania (focused skin picking), oraz podskali stylu automatycznego kresie cech temperamentu. Istotne statystycznie różnice wykryto w przypadku podskal Perseweratywności, Wytrzymałości, Żwawości i Reaktywności. Osoby skubiące skórę charakteryzowały się większą perseweratywnościa i reaktywnościa, niż osoby nie skubiące skóry, a także mniejszą wytrzymałością i żwawościa. Badane grupy nie różniły się natomiast pod względem aktywności i wrażliwości. Wyniki przedstawia Tabela 1.

Dodatkowo wykonano analizę mającą na celu sprawdzenie, czy występują różnice w zakresie cech temperamentu pomiędzy osobami, które różnią się stylem skubania skóry. W celu dokonania porównań grupę osób

Tabela 1

Porównanie średnich wartości cech temperamentalnych w grupie osób skubiących skórę $(n=89)$ i w grupie kontrolnej $(n=125)$

\begin{tabular}{|c|c|c|c|c|c|c|}
\hline & Grupa & $M$ & $S D$ & $t$ & $d f$ & $p$ \\
\hline Aktywność & $\begin{array}{l}\text { Osoby skubiące skórę } \\
\text { Grupa kontrolna }\end{array}$ & $\begin{array}{l}9.06 \\
9.85\end{array}$ & $\begin{array}{l}5.18 \\
4.49\end{array}$ & 1.18 & 212 & .23 \\
\hline Wrażliwość & $\begin{array}{l}\text { Osoby skubiące skórę } \\
\text { Grupa kontrolna }\end{array}$ & $\begin{array}{l}14.71 \\
14.30\end{array}$ & $\begin{array}{l}3.10 \\
3.36\end{array}$ & -.91 & 212 & .35 \\
\hline Perseweratywność & $\begin{array}{l}\text { Osoby skubiące skórę } \\
\text { Grupa kontrolna }\end{array}$ & $\begin{array}{l}15.57 \\
13.56\end{array}$ & $\begin{array}{l}4.85 \\
4.09\end{array}$ & -4.28 & 212 & $.00002^{\star \star *}$ \\
\hline Wytrzymałość & $\begin{array}{l}\text { Osoby skubiące skórę } \\
\text { Grupa kontrolna }\end{array}$ & $\begin{array}{l}7.30 \\
9.31\end{array}$ & $\begin{array}{l}4.08 \\
4.85\end{array}$ & 3.18 & 212 & $.001^{* * *}$ \\
\hline Żwawość & $\begin{array}{l}\text { Osoby skubiące skórę } \\
\text { Grupa kontrolna }\end{array}$ & $\begin{array}{l}12.15 \\
14.09\end{array}$ & $\begin{array}{l}4.22 \\
3.95\end{array}$ & 3.43 & 212 & $.007^{* * *}$ \\
\hline Reaktywność & $\begin{array}{l}\text { Osoby skubiące skórę } \\
\text { Grupa kontrolna }\end{array}$ & $\begin{array}{l}13.16 \\
11.25\end{array}$ & $\begin{array}{l}3.92 \\
4.52\end{array}$ & -3.21 & 212 & $.001^{* * *}$ \\
\hline
\end{tabular}

(automatic skin picking). Każda z podskal składa się z 6 stwierdzeń, osoba badana ocenia, w jakim stopniu dane stwierdzenie jej dotyczy, udzielajacc odpowiedzi na skali 5-punktowej (od 1 do 5). W badaniach użyto polskiego tłumaczenia Skali MIDAS (a Cronbacha dla polskiego tłumaczenia podskali stylu automatycznego wynosiła 0,87, dla podskali stylu skoncentrowanego - .88).

Ankieta dotycząca skubania skóry. W badaniach wykorzystano także ankietę zawierająca pytania dotyczące preferowanych stylów skubania (automatycznego i skoncentrowanego na czynności), stresu odczuwanego w związku ze skubaniem skóry, trudności w funkcjonowaniu społecznym związanych ze skubaniem skóry (takich jak opuszczanie zajęć na studiach, opuszczanie pracy, unikanie spotkań towarzyskich, wpływu skubania skóry na pogorszenie jakości życia towarzyskiego, zawodowego oraz związków partnerskich). Celem ankiet było uszczegółowienie i ujednoznacznienie odpowiedzi udzielanych przez osoby badane w skalach SPS i MIDAS.

\section{WYNIKI}

Porównanie wyników uzyskanych przez osoby skubiące skórę i osoby bez objawów dermatillomanii - wykonane przy użyciu testu $t$-Studenta (dla wszystkich sześciu podsmal FCZ-KT) wykazało, że grupy te różnią się w za- skubiących skórę podzielono na dwie podgrupy: osoby, które skubią skórę w sposób automatyczny (w tej grupie uwzględniono również osoby charakteryzujace się mieszanym stylem skubania skóry, czyli te, które czasem skubią skórę automatycznie, a czasem świadomie) oraz osoby, które skubią skórę koncentrując się na czynności skubania (czyli są świadome, że skubią skórę w chwili, kiedy to robia). Do grupy pierwszej (skubanie automatyczne oraz mieszane) trafiło 57 osób (średnia wieku 21.64, $S D=1.82$ ), natomiast do drugiej (tylko skubanie świadome) - 35 osób (średnia wieku 22.31, $S D=2.12$ ). Średni wiek osób z obydwu grup nie różnił się istotnie $(t=-1.59, d f=90, p<.11)$. Grupy te porównano pod względem wyników uzyskanych w Skali SPS oraz wyników wszystkich sześciu poskal FCZ-KT. Grupy różniły się nasileniem objawów patologicznego skubania skóry (badani prezentujacy styl automatyczny uzyskali istotnie wyższe wyniki w skali SPS) oraz poziomem wytrzymałości (wyższy wynik u osób skubiących skórę świadomie) i reaktywności (wyższy wynik u osób skubiących automatycznie). Wyniki przedstawia Tabela 2.

\section{OMÓWIENIE WYNIKÓW}

Wyniki badań potwierdziły hipotezę o związkach między cechami temperamentu a skubaniem skóry. Osoby sku- 
Tabela 2

Porównanie średnich wartości cech temperamentalnych w grupie osób skubiących skórę automatycznie lub czasem automatycznie a czasem ze skupieniem $(n=57)$ oraz skubiących, będąc skoncentrowanymi na tej czynności $(n=35)$

\begin{tabular}{|c|c|c|c|c|c|c|}
\hline & Grupa & $M$ & $S D$ & $t$ & $d f$ & $p$ \\
\hline SPS & $\begin{array}{l}\text { Skubanie skoncentrowane } \\
\text { Skubanie automatyczne }\end{array}$ & $\begin{array}{l}3.34 \\
5.45\end{array}$ & $\begin{array}{l}2.98 \\
4.00\end{array}$ & 2.69 & 90 & $.008^{* *}$ \\
\hline Aktywność & $\begin{array}{l}\text { Skubanie skoncentrowane } \\
\text { Skubanie automatyczne }\end{array}$ & $\begin{array}{l}9.71 \\
8.49\end{array}$ & $\begin{array}{l}4.13 \\
5.29\end{array}$ & 1.236 & 90 & .220 \\
\hline Wrażliwość & $\begin{array}{l}\text { Skubanie skoncentrowane } \\
\text { Skubanie automatyczne }\end{array}$ & $\begin{array}{l}14.29 \\
14.47\end{array}$ & $\begin{array}{l}3.38 \\
3.19\end{array}$ & -.268 & 90 & .789 \\
\hline Perseweratywność & $\begin{array}{l}\text { Skubanie skoncentrowane } \\
\text { Skubanie automatyczne }\end{array}$ & $\begin{array}{l}14.89 \\
16.11\end{array}$ & $\begin{array}{l}3.41 \\
2.76\end{array}$ & -1.878 & 90 & .064 \\
\hline Wytrzymałość & $\begin{array}{l}\text { Skubanie skoncentrowane } \\
\text { Skubanie automatyczne }\end{array}$ & $\begin{array}{l}8.29 \\
6.33\end{array}$ & $\begin{array}{l}4.36 \\
3.76\end{array}$ & 2.271 & 90 & $.026^{*}$ \\
\hline Żwawość & $\begin{array}{l}\text { Skubanie skoncentrowane } \\
\text { Skubanie automatyczne }\end{array}$ & $\begin{array}{l}12.63 \\
11.68\end{array}$ & $\begin{array}{l}4.32 \\
4.12\end{array}$ & 1.047 & 90 & .298 \\
\hline Reaktywność & $\begin{array}{l}\text { Skubanie skoncentrowane } \\
\text { Skubanie automatyczne }\end{array}$ & $\begin{array}{l}12.03 \\
14.16\end{array}$ & $\begin{array}{l}3.54 \\
3.73\end{array}$ & -2.708 & 90 & $.008^{* *}$ \\
\hline
\end{tabular}

biące skórę charakteryzują się większą perseweratywnością i reaktywnościa, niż osoby, u których to zachowanie nie występuje. Perseweratywność jako cecha temperamentu wydaje się sprzyjać występowaniu i utrzymywaniu się powtarzalnych, stereotypowych zachowań, takich jak skubanie, drapanie, dłubanie czy pocieranie skóry. Zachowania te, w niepatologicznej formie powszechnie występujące w ogólnej populacji (Hayes, Storch i Berianga, 2009), u osób z wysoką perseweratywnością moga przekształcać się w utrwalone nawyki, a następnie nabierać cech zaburzenia. W tej grupie osób takie powtarzalne, zrytualizowane czynności mogą pełnić funkcję skutecznego regulatora poziomu pobudzenia, natomiast u osób o niskiej perseweratywności mechanizm ten prawdopodobnie nie jest tak skuteczny, a więc zachowania polegające na skubaniu skóry nie będą wykazywać tendencji do utrwalania się. Zwiększona perseweratywność może także sprzyjać wystapieniu jednej z charakterystycznych cech patologicznego skubania skóry, jaka jest niezdolność do zaprzestania skubania, czyli niezdolność do wyhamowania raz zainicjowanej czynności. Osoby cierpiące na PSP często relacjonuja, że w trakcie epizodu skubania doświadczaja stanu podobnego do transu, który utrudnia im przerwanie uszkadzania skóry nawet wtedy, gdy sa świadome, że czynność ta prowadzi do niekorzystnych zmian w wyglądzie zewnętrznym. Świadomość negatywnych następstw skubania nie działa w tym przypadku jako czynnik wystarczająco silny, by powodować przerwanie raz rozpoczętej czynności nawet wtedy, gdy osoba skubiąca skórę deklaruje silną motywację do zaprzestania skubania.

Reaktywność, druga z cech temperamentu, których związek z dermatillomania przewidywano w hipotezach, także okazała się istotnie bardziej nasilona u osób skubiacych skórę, w porównaniu z osobami bez objawów PSP. Związana z reaktywnością tendencja do silnego reagowania na bodźce emocjonalne może skłaniać osoby cierpiące na dermatillomanię do wytwarzania mechanizmów regulujących nadmierne pobudzenie. Współwystępowanie wysokiej reaktywności i podwyższonej perseweratywności może powodować, że osoby te wykształcaja patologiczne sposoby regulowania napięcia, oparte na wykonywaniu powtarzalnych, jednostajnych ruchów, takich jak skubanie, drapanie i pocieranie skóry, zamiast poszukiwać bardziej adaptacyjnych metod regulowania nieprzyjemnych stanów emocjonalnych.

Zwiększona reaktywność odpowiada za łatwość inicjowania zachowań, których celem miałoby być regulowanie nadmiernego pobudzenia, podczas gdy nasilona perseweratywność utrudnia ich przerywanie, w warunkach, gdy już się pojawiły. Interpretację tę wspiera także - wykazana w badaniach - niska wytrzymałość i żwawość osób skubiących skórę. Ponieważ osoby te maja ograniczoną zdolność do adekwatnego reagowania w warunkach długotrwałej i silnej stymulacji, ich reakcje w sytuacjach przeciążenia będą przyjmować formę nieadekwatnych i nieadaptacyjnych działań, takich jak dłubanie i pocieranie skóry. Działania te, ze względu na niską wytrzymałość osób cierpiacych na PSP, mogą być inicjowane już w chwili wystapienia stymulacji i będa pojawiły się często, także w warunkach stosunkowo niewielkiego przeciążenia, a następnie, ze względu uczucie ulgi i odprężenia, które przynosza, będą miały tendencję do utrwalania się i przechodzenia w patologiczną formę. Obniżona żwawość dodatkowo ogranicza możliwy zakres działań osób z PSP, obniżając tempo reagowania i możliwości elastycznego zmieniania zachowań w zależności od wymogów sytuacji. Taka konfiguracja cech temperamentalnych - podwyższona perseweratywność i reaktywność oraz obniżona wytrzymałość i żwawość - wydaje się sprzyjać pojawianiu się i utrwalaniu zachowań polegających na skubaniu skóry. Różnice temperamentalne mogą więc być rozważane jako istotny czynnik rozwoju dermatillomanii. 
U osób o wysokiej reaktywności i perseweratywności oraz niskiej wytrzymałości, skubanie skóry może pełnić funkcję regulatora poziomu pobudzenia (obniżając zbyt wysoki poziom pobudzenia). W związku z tym, jednym z kierunków pomocy osobom cierpiacym z powodu patologicznego skubania skóry, byłoby uczenie ich bardziej adaptacyjnych sposobów regulacji poziomu pobudzenia i emocji, jak również technik radzenia sobie ze stresem. Przydatne mogłoby okazać się również uczenie sposobów monitorowania poziomu pobudzenia, tak, aby podejmować świadome działania zmierzające do jego regulacji, zanim poziom aktywacji stanie się zbyt wysoki.

Uwzględnienie $\mathrm{w}$ badaniach stylów skubania skóry: automatycznego i przebiegającego świadomie, pozwoliło stwierdzić, że osoby reprezentujące styl automatyczny lub mieszany charakteryzują się większą reaktywnościa i mniejszą wytrzymałościa, w porównaniu z osobami, które skubią skórę świadomie. Grupy wyróżnione ze względu na styl skubania nie różniły się natomiast pod względem perseweratywności i żwawości, które to cechy wydają się być wspólne dla wszystkich osób cierpiacych na PSP. Osoby skubiace skórę automatycznie charakteryzowały się także większym nasileniem objawów dermatillomanii, w porównaniu z osobami skubiącymi świadomie. Może to oznaczać, że u osób cechujących się szczególnie wysoka reaktywnościa i niska wytrzymałościa, zachowania polegajace na skubaniu skóry występują szczególnie często. $\mathrm{W}$ poczatkowej fazie rozwoju zaburzenia pełnia one funkcję mechanizmu umożliwiającego rozładowanie napięcia, z czasem jednak ulegaja automatyzacji i zaczynaja przebiegać poza kontrola świadomości. U osób skubiących skórę automatycznie, ze względu na częste występowanie skubania i jego nieświadomy przebieg, obecnych będzie więcej negatywnych następstw dermatillomanii, takich jak deformacje, przebarwienia i infekcje skóry, a także następstw psychologicznych w postaci przewlekłego stresu, poczucia wstydu, winy, tendencji do izolowania się. Osobom tym trudniej jest także powstrzymywać się od skubania skóry lub choćby ograniczyć je w stopniu pozwalającym na leczenie zadrapań, ponieważ czynności zautomatyzowane i przebiegające poza świadomością trudniej poddać kontroli, niż czynności inicjowane świadomie.

Pomagając osobom, które skubią skórę automatycznie i chciałyby uwolnić się od tego zachowania, warto byłoby nakłonić je do obserwacji i notowania typów sytuacji, (jak również stanów emocjonalnych, które im towarzysza), $\mathrm{w}$ jakich zdarza im się to automatyczne zachowanie. Znając rodzaje sytuacji, w których pojawiaja się objawy, mogliby $\mathrm{w}$ podobnych sytuacjach $\mathrm{w}$ przyszłości świadomie utrzymywać uwagę na tym, aby obserwować tendencję, jak również mogliby prewencyjnie podejmować działania regulujące poziom pobudzenia oraz emocje w sposób bardziej adaptacyjny. Znajac własne cechy temperamentalne oraz sytuacje, w których zdarza im się skubanie skóry, osoby mogłyby również tak planować swoją aktywność (np. podział pracy na stosowne odcinki czasu intensywnej pracy i przerw), aby utrzymywać poziom pobudzenia na najbardziej optymalnym dla siebie poziomie.

\section{LITERATURA}

Arnold, L.M., McElroy, S.L., Mutasim, D.F., Dwight, M.M., Lamerson, C.L., Morris, E.M. (1998). Characteristic of 34 adults with psychogenic excoriation. Journal of Clinical Psychiatry, 59, 509-514.

Arnold, L.M., Auchenbach, M.B., McElroy, S.L. (2001). Psychogenic excoriation. CNS Drugs, 15, 5, 351-359.

Arzeno-Ferro, Y., Paiva-Almeida, V., Richter-Bedin, N., Rosa, R., D'Arringo-Busnello, D. (2006). Impulsivity and compulsivity in patients with trichotillomania or skin picking compared with patients with obsessive - compulsive disorder. Comprehensive Psychiatry, 47, 282-288.

Bohne, A., Wilhelm, S., Keuthen, N., Baer, L., Jenike, M. (2002). Skin picking in German students: prevalence, phenomenology, and associated characteristics. Behavior Modification 26, 320-339.

Calikuşu, C., Yücel, B., Polat, A., Baykal, C. (2003). The relation of psychogenic excoriation with psychiatric disorders: a comparative study. Comprehensive Psychiatry, 44, 256-261.

Calikuşu, C., Kucukgoncu, S., Bestepe, E. (2011). Skin picking in Turkish students. European Psychiatry, P03 - 534. Abstract.

Deckersbach, T., Wilhelm, S., Keuthen, N. (2003). Self - injurious skin - picking: clinical characteristic, assessment methods and treatment modalities. Brief Treatment and Crisis Intervention, 3, 249-260.

Fruensgaard, K. (1984). Neurotic excoriations: A controlled psychiatric examination. Acta Psychiatr Scand Suppl, $312,1-52$.

Hajack, G., Franklin, M.E., Simons, R.F., Keuthen, N.J. (2006). Hairpulling and skin picking in relation to affective distress and obsessive - compulsive symptoms. Journal of Psychopathology and Behavioral Assessment, 3, 179-187.

Hayes, S.L., Storch, E.A., Berianga, L. (2009). Skin picking behaviors: An examination of prevalence and severity in a community sample. Anxiety Disorders, 23, 314-319.

Heszen, I. (2012). Temperament and coping activity under stress of changing intensity over time. European Psychologist, 17, 4, 326-336.

Keuthen, N.J., Deckersbach, T., Wilhelm, S., Hale, E., Fraim, C., Baer, L., O'Sullivan, R.L., Janike, M.A. (2000). Repetitive skin picking in a student population and comparison with sample of self - injurious skin pickers. Psychosomatic, 41, 210-215.

Keuthen, N.J., Wilhelm, S., Deckersbach, T., Engelhard, I.M., Forker, A.E., Baer, L., Janike, M.A. (2001). The skin picking scale. Scale construction and psychometric analyses. Journal of Psychosomatic Research, 50, 337-34.

Keuthen, N.J., Koran, L.M., Aboujaoude, E., Large, M.D., Serpe, R.T. (2010). The prevalence of skin picking in US adults. Comprehensive Psychiatry, 51, 183-186.

Locher, C., Simeon, D., Niehaus, D.J., Stein, D.J. (2002). Trichotillomania and skin-picking: A phenomenological comparison. Depression and Anxiety, 15, 2, 83-86.

Marszał-Wiśniewska, M., Goryńska, E., Strelau, J. (2012). Mood change in stressful exam situation: The modifying role of temperament and motivational tendencies. Personality and Individual Differences, 52, 7, 839-844.

Neziroglu, F., Rabinowitz, D., Breytman, A., Jacofsky, M. (2008). Skin picking phenomenology and severity comparison. Primary Care Companion to the Journal of Clinical Psychiatry, 10, 306-312. 
Odlaug, B.L., Brian, L., Grant, J.D. (2008). Clinical characteristic and medical complications of pathologic skin picking. General Hospital Psychiatry, 30, 61-66.

Odlaug, B.L., Kim, S.W., Grant, J.D. (2010). Quality of life and clinical severity in pathological skin picking and trichotillomania. Journal of Anxiety Disorders, 24, 823-829.

Penzel, F. (2003). The hair - pulling problem. A complete guide to trichotillomania. New York: Oxford University Press.

Prochwicz, K., Starowicz, A. (2012). Dermatillomania. Objawy, przebieg i następstwa patologicznego skubania skóry. Neuropsychiatria i Neuropsychologia, 7, 4, 197-205.

Prochwicz, K., Kałużna-Wielobób, A., Starowicz, A. (2014). Emotions and activation level in individuals with skin picking behavior. 22nd European Congress of Psychiatry. Munich, Germany 1-4 March 2014.

Prochwicz, K., Kałużna-Wielobób, A., Starowicz, A. (w recenzji). Examining the link between emotions, activation and skin picking behaviors in non - clinical sample.

Simeon, D., Stein, D.J., Gross, S., Islam, N., Schmeidler, J., Hollander, E. (1997). A double-blind trial of fluoxetine in pathologic skin picking. The Journal of clinical psychiatry, 58, 8, 341-347.

Snorrason, I., Smári, J., Olafsson, R.P. (2010). Emotion regulation in pathological skin picking: findings from a non - treatment seeking sample. Journal of Behavior Therapy and Experimental Psychiatry, 41, 238-245.

Stein, D.J., Grant, J.E., Franklin, M.E., Keuthen, N, Lochner, C., Singer, H.S., Wooods, D.W. (2010). Trichotillo- mania (hair pulling disorder), skin picking disorder, and stereotypic movement disorder: toward DSM-V. Depression and Anxiety, 27, 611-626.

Strelau, J. (2006a). Psychologia różnic indywidualnych. Warszawa: Wydawnictwo Naukowe SCHOLAR.

Strelau, J. (2006b). Temperament jako regulator zachowania - z perspektywy półwiecza badań. Gdańsk: Gdańskie Wydawnictwo Psychologiczne.

Strelau, J., Doliński D. (red.). (2011). Psychologia akademicka. Podręcznik (t.1). Gdańsk: GWP

Strelau, J., Zawadzki, B. (2011). Fearfulness and anxiety in research on temperament. Temperamental traits are related to anxiety disorders. Fearfulness and anxiety in research on temperament: Temperamental traits are related to anxiety disorders. Personality and Individual Differences, 50, 7, 907-915.

Walther, M.R., Flessner, C.A., Conelea, C.A., Woods, D.W. (2009). The Milwaukee Inventory for the dimensions of adult skin picking (MIDAS): Initial development and psychometric properties. Journal of Behavior Therapy and Experimental Psychiatry, 40, 129-135.

Wilhelm, S., Kauthen, N.J., Deckersbach, T. (1999). Self injurious skin picking; clinical characteristic and comorbidity. Journal of Clinical Psychiatry, 60, 454-459.

Zawadzki, B., Strelau, J. (1997). Formalna Charakterystyka Zachowania - Kwestionariusz Temperamentu (FCZ-KT). Warszawa: Pracownia Testów Psychologicznych Polskiego Towarzystwa Psychologicznego. 